\title{
EFL Students' and Teachers' Perceptions and Practices of the Writing Tasks in Grades 11 and 12: the Case of Liyew Asres Zewudie General Secondary and Preparatory School, East Gojjam Zone, Ethiopia
}

\author{
Tegegne Bekalu Molla \\ Lecturer at Mekdela Amba University, College of Social Sciences and Humanities, Department of English \\ Language and Literature, Ethiopia
}

\begin{abstract}
The general objective of this study was to investigate EFL students' and teachers perceptions and practices of the writing tasks in grades 11 and 12 in one general secondary and preparatory school context. The study was conducted in Liyew Asres Zewudie General Secondary and Preparatory School. The study employed convergent parallel mixed research design so as to achieve the intended objectives of the study. The data for this study were collected through questionnaires, interviews and classroom observations. Questionnaires were mainly prepared and administered to both 120 students and 18 English language teachers who had been selected using systematic random sampling and comprehensive sampling respectively. Twelve students from the sample representatives and six English language teachers were interviewed. Eight preparatory sections which were taught by eight different teachers were selected purposively and observed on the basis of an observation checklist. Then, the data were analyzed quantitatively using frequency, percentage and mean value, and qualitatively in words. The findings of the study disclosed that most of the students had unfavorable perceptions about the writing tasks of the textbooks and their classroom practices of the writing tasks were profoundly poor, which was in contradiction with the tenets of TBW. The study also revealed that the majority of teachers had fairly positive perceptions about the effects and relevance of writing tasks on improving the learners' writing ability although they were proved to have negative perceptions about the roles students and teachers should play in practicing the writing tasks.. It was concluded that the teachers' practices of the writing tasks were not in line with the tenets of TBW and hence the roles both teachers and students should play in each phase of the writing tasks were not properly played. Finally, the researcher forwarded recommendations to teacher educators, education bureaus, school authorities, teachers, students and other concerned bodies to make their contributions so as to effectively overcome the identified gaps.

Keywords: Writing task, Perception, Practice, Task based writing, Teachers, Students ,Task based language teaching
\end{abstract}

DOI: $10.7176 / \mathrm{JEP} / 11-25-04$

Publication date:September $30^{\text {th }} 2020$

\section{INTRODUCTION}

Writing is a difficult skill to accomplish particularly for English as Foreign Language (EFL) students. It is a complex process that requires writers to explore thoughts and ideas, and make them visible and concrete .In relation to this, Flynn \& Stainthorp (2006:54) state that "Writing is a highly complex task that requires the orchestration of a number of different activities simultaneously and thereby places great demands on the cognitive system.'

In spite of the difficult nature of writing, the ability to write well in English is an indispensable quality in the world of academics and other concerns of life. However, it is often said that the level of English is declining in Ethiopia. Schools, training institutions, English teachers, colleges and universities are increasingly under criticisms from the public and the stakeholders because of the deteriorating English language proficiency of students (Amlaku, 2013). Particularly, as far as writing is concerned, studies in Ethiopia (Abas, 2016 and Meseret, 2012) have shown that the writing ability of many Ethiopian students is by far less than what is expected of them. The cause of this may be of several reasons.

Probably, one of the causes could be the way writing tasks are used in teaching writing and students' perception of the tasks. Perhaps, part of the problem can be attributed to students' and teachers' misunderstanding of the nature of task-based approach (TBA) to language teaching and learning which is currently being practiced in many parts of the world as a component of Communicative Language Teaching (CLT). Therefore, in order to raise the knowledge and skills of both students and teachers in using tasks properly, the language teaching materials and classes need to be supported by appropriate task- based teaching materials.

Accordingly, in the Ethiopian context of English language teaching and learning, the students' textbooks of secondary schools in general and grade 11 and 12 in particular were studied to be of greatly task based oriented (Meron, 2015 and Tariku, 2013). According to the conclusions they made and the personal evaluation of the researcher, the contents as input are familiar to the learners and meet the needs and interests of the students; the 
writing tasks are appropriate to the communicative goals of TBW; the three phases of writing tasks are clearly indicated both in the syllabuses and textbooks; the objectives of the writing tasks are explicitly stated; the roles both students and teachers should play in each phase of the writing tasks are vividly stated not only in the textbooks but also in the teacher's guide and syllabuses. In these regard, the textbooks have actually been designed to enable students to learn the language meaningfully by practicing the writing tasks incorporated in the textbooks in a Task Based Writing (TBW) basis.

Though appropriate task designing is essential for the writing class, it cannot be a sufficient condition in itself to foster language learning. The students' and teachers' perceptions and actual practices need to be considered with the intention of having a better understanding of how writing tasks has been perceived and practiced.

As Richardson (1994) pointed out, one should focus on teachers' perceptions and practices in order to understand how teachers make sense of teaching and learning. Therefore, the way tasks are perceived and used in a particular context in relation to other pedagogical considerations will always be significant. As a result, knowledge of students' belief and how they learn writing is very important to know their feelings about the different approaches to the teaching of writing. And, effective teaching is not only about perceptions of certain teaching method but it is also about understanding and implementing principles of teaching or learning in that method.

Researches on the area of study were conducted by Ismail, (2011); Asadifard, (2013); Al-Azani, (2015) and Kamil, (2011). The first two studies are on students' perceptions of ESL writing and on EFL writers' perception on academic writing respectively. Both of them focused on investigating the writers' perceptions alone. The latter two researches were on teachers' perceptions regarding the methods or strategies used in teaching writing. These all studies were conducted abroad and mainly focused on how writing is perceived in an ESOL context.

Some local studies have also been conducted so far on the area under study by different researchers such as Meseret (2012), Tagese (2012) and Taye (2008). However, these researchers conducted their studies at higher institutions.

The much related local works in the area under study are the researches of Beyene (2008), Daniel (2010) and Demelash (2011). The first two were aimed at exploring teachers' and students' perceptions and practices communicative language teaching in general whereas the last one was conducted on teachers' and students' perception and practices of task-based activities. His study focused on task-based activities in general, but not on writing tasks in particular. Furthermore, the research design he used (qualitative) is different from the research framework employed in this study (convergent parallel mixed research design).

From this, the researcher concluded that some works have been done on the issue so far which were especially limited to the higher institutions, and there might be few in secondary school context. As far as the effort made so as to review related works is concerned, almost there are few studies which have been conducted to study teachers' and students' perceptions and practices of writing tasks in secondary school context particularly in Liyew Asres Zewudie General Secondary and Preparatory School. Hence, this research aimed at investigating EFL students' and teachers' perceptions and practices of the writing tasks in grades eleven and twelve textbooks. To attain this objective, this research attempted to address the following specific questions.

1. What perceptions do students hold on writing tasks of the textbooks?

2. How do students practice learning writing tasks of the textbooks?

3. What perceptions do English language teachers hold on writing tasks of the textbooks?

4. How do English language teachers practice teaching writing tasks of the textbooks?

\section{REASEARCH METHODOLOGY}

\subsection{Research Design}

The research framework used in this study was convergent parallel mixed research design which made use of both quantitative and qualitative methods. This method was found to be appropriate for this study which aimed at students' and teachers' perceptions and practices of the writing tasks. The basic assumption behind using this method is that it provides better understanding of the research problem and answers the research questions than any other approach (Cresswel 2014). In relation to this, Ary et al (2010: 567) states that mixed methods research can take advantage of the combined strengths of qualitative and quantitative approaches and can use the strengths of one method to overcome the weaknesses of another. The combination may produce more complete understandings of the phenomenon or more complete knowledge to inform theory or practice. Therefore, if mixed method offers a better understanding of the research problem and is preferable to a single method design, then it was worth considering for the purpose of investigating students' and teachers' perceptions and practices of the writing tasks.

\subsection{Participants of the Study}

The participants of the study were grade 11 and 12 students and English language teachers of Liyew Asres Zewudie General Secondary and Preparatory School. Only grade eleven and twelve students were selected because in 
contradiction with the fact that these students were about to join universities and higher educational institutions where at least their reasonable writing ability is demanded, they were found to be poor in writing skill which could have been associated with how task based writing is perceived and practiced.

\subsection{Sampling Techniques}

For this study, the researcher employed systematic random sampling technique to select representatives of the whole grade eleven and twelve students for the questionnaire. It is a preferable sampling technique to be used in the context where using simple random sampling is tiresome and time taking. Systematic sampling resembles simple random sampling because all of the units in the sampling frame initially have an equal chance of being selected (William and Marilynn, 202:174). The total number of preparatory students was 840 of which $120(14.3 \%)$ of them were selected as a representative samples.

The researcher used all eighteen English language teachers of Liyew Asres Zewudie General Secondary and preparatory school as a sample using comprehensive sampling. For the students participated in the interview, simple random sampling was employed based on the assumption that it is recommended to be used if the list of the population is manageable since it provides an equal probability of being selected for each individual (Cresswell, 2014). Therefore, twelve (10\%) students were selected from the total sample representatives $(\mathrm{n}=120)$. Finally, with regard to the classroom observations, eight sections which were taught by eight different teachers were chosen on the basis of convenience sampling.

\subsection{Instruments of Data Collection}

According to Patton (1990: 244), multiple data gathering instruments are sought and used because no single source of information can be trusted. Therefore, the researcher employed three kinds of instruments: questionnaire, interview and classroom observation.

\subsubsection{Questionnaire}

A questionnaire is an appropriate instrument for collecting data on what your participants think or believe about certain issues and is a very convenient instrument because a substantial amount of data can be gathered from a group of participants in a fairly short period of time (Griffee, 2012: 138). Hence, the researcher used questionnaires for both the students and teachers to find out their perceptions and practices about the writing tasks.

All items of the questionnaires were likert scale type close-ended questions by realizing that likert scale questions combine the opportunity for a flexible response with the ability to determine different forms of quantitative analysis. They afford the researcher the freedom to combine measurement with opinion, quantity and quality (Cohen et al., 2000). Both students' and teachers' questionnaires had two sections each which dealt with perceptions and practices of writing tasks respectively. The questions of the questionnaires were designed on the basis of literatures related to TBLT such as Nunan (2004), Willis (1996) and Ellis (2003).

\subsubsection{Interview}

Semi-structured interviews were administered to both preparatory students and English language teachers to carefully examine their perceptions of the writing tasks. The rationale behind using semi-structured interview is that it "increases the comprehensiveness of the data and makes data collection somewhat systematic for each respondent" (ibid: 271). The interviews were mainly used in order to triangulate what the students and teachers reported and said about their perceptions of the writing tasks of the textbooks converge.

\subsubsection{Classroom Observation}

According to Robson (2002:310), observation gives the firsthand account of situation under study; and 'combined' with other data collecting tools, it allows for a holistic interpretation of the situations which are being studied. Bearing this in mind, classroom observations were made in use to have a direct experience on what practices English teachers and students had on the writing tasks of the textbooks and how they practiced them in the actual teaching-learning process. Totally, eight direct classroom observations were made and the overall practices and reactions between the teachers and the students as well as among the students themselves were recorded on the observation checklist. Finally, the average remarks of each item were used in the analysis.

\subsection{Data Collection Procedures}

To collect relevant information from the participants of the study, after gathering the sample representative students in the school hall, the purpose and importance of the research in general and the questionnaire in particular were explained to them briefly. Following this, the researcher administered the questionnaires directly to the participants and they were given enough time for each question. The teachers' questionnaire was administered to eighteen English language teachers the following day and all items of the questionnaire were answered.

After the questionnaire data were collected, the interview was made to the sample representative students so as to carefully examine their feelings about writing tasks. Following this, the teachers' interview was made to six preparatory English language teachers. The interviews of both the sample representative students and teachers were video recorded to increase the validity of the data. 
Finally, in order to see the way the teachers teach and the reaction of the students in the actual classroom situation, eight classroom observations were made. In general, during data collection, both quantitative and qualitative data collection instruments were used, and information from the data were triangulated so as to increase the validity and reliability of the study.

\subsection{Method of Data Analysis}

The researcher used both quantitative and qualitative methods to analyze the collected data through the employed data gathering tools. The quantitative method was used to tabulate and analyze the data gathered through the questionnaires and the classroom observations while the responses of the interviews were analyzed qualitatively in words. In order to ease the analysis and discussion, the responses of both students' and teachers' questionnaires for perception focused items were categorized into the following three thematic units:

1. Perceptions concerning the effects of writing tasks on improving the teaching and or learning of writing

2. Perceptions concerning the relevance of writing tasks

3. Perceptions concerning students' and teachers' roles in the writing tasks

The data gathered through the classroom observations were also grouped into two themes:

1. Instructional activities

2. The roles of students and teachers in the three task phases which were further classified into three sub-themes (pre-task, while-task, and post-task phases).

After categorizing the thematic units so as to analyze the quantitative responses, first, the raw data collected through the questionnaires and classroom observations were tailed, tabulated and then frequency that shows the number of respondents for each one of the items and their corresponding percentage were made to be read.

The quantitative analysis was made based on Likert-type analysis. The Likert-type items which were designed to find out students' and teachers' perceptions about writing tasks and their actual classroom practices were given numerical scores. Accordingly, for favorable items (statements directly related to principles of TBLT or TBW) were coded as: 'strongly agree' $(\mathrm{SA})=5$, 'Agree' $(\mathrm{A})=4$, 'Undecided' $(\mathrm{U})=3$, Disagree $(\mathrm{D})=2$ and 'Strongly disagree' $(\mathrm{SD})=1$. But the unfavorable items (those which were designed to crosscheck the teachers' view and address non-communicative aspects), were coded conversely as: 'strongly agree' (SA) = 1, 'Agree' $(\mathrm{A})=2$, 'Undecided' $(\mathrm{U})=3$, 'Disagree' $=4$ and 'Strongly disagree' $=5$. In the same way, the items of the questionnaire for classroom practice were coded as : 'Always' $(A)=5$, 'Often' $(\mathrm{O})=4$, 'Sometimes' $(\mathrm{ST})=3$, Rarely $(\mathrm{R})=2$ and $\operatorname{Never}(\mathrm{N})=1$ for favorable items whereas the unfavorable items took the opposite coding: 'Always' $(\mathrm{A})=1$, 'Often' $(\mathrm{O})=2$, 'Sometimes' $(\mathrm{ST})=3$, 'Rarely' $(\mathrm{R})=4$ and 'Never' $(\mathrm{N})=5$. Moreover, the items of the classroom observation checklist were coded as: 'Effectively' $(\mathrm{E})=3$, 'Averagely' $(\mathrm{A})=2$ and 'Poorly' $(\mathrm{P})=1$.

After calculating the frequency and percentage of each item, their corresponding mean scores of each item were calculated in accordance with the coding numerals. A higher mean score implies the respondents' high perception or frequent classroom practices of the writing tasks whereas lower mean value indicates negative perceptions or unfavorable writing practices in the classroom. Therefore, the analysis of the questionnaires and classroom observations were carried out by comparing the calculated percentage, mean values and frequencies.

The qualitative method, on the other hand, was employed for the analysis of the data collected through the students' and teachers' interviews. The analysis was made according to the order of the instruments of data collection and in accordance with the research questions.

\section{RESULTS AND DISCUSSION}

\subsection{Results and Discussion of the Students' Questionnaire}

The purpose of the questionnaire was to reveal the students' perceptions and practices of writing tasks. The questionnaire consists of two sections with a total of 30 items. In section one, 22 items, which were designed to identify students' conceptual views about the nature of the writing tasks, were given numerical scores with five point Likert scale ranging from 'strongly agree' to 'strongly disagree'. Similarly, in section two, 8 items, which were designed to identify students' actual classroom practices of writing tasks, were given five point Likert scale ranging from 'always' to 'never'. In this manner, the data obtained from the numerical values of the five point Likert-type scales were tabulated under each theme using frequencies, percentages and mean. 


\subsubsection{Results and Discussion of Students' Questionnaire for Perception}

Theme one: Perceptions concerning the effects of writing tasks on improving the learning of writing.

Table 1: Students' responses about their perceptions concerning the effects of writing tasks on improving the learning of Writing.

\begin{tabular}{|c|c|c|c|c|c|c|c|c|}
\hline \multirow[b]{3}{*}{ Item } & \multirow[b]{3}{*}{ Statements } & \multirow[b]{3}{*}{ SV } & \multicolumn{5}{|c|}{ Responses } & \multirow{3}{*}{ Mean } \\
\hline & & & SA & A & $\mathrm{U}$ & $\mathrm{D}$ & SD & \\
\hline & & & 5 & 4 & 3 & 2 & 1 & \\
\hline \multirow[t]{2}{*}{1} & I believe the writing tasks in the textbook enhance my & $\mathrm{F}$ & 11 & 16 & 48 & 24 & 21 & \multirow[t]{2}{*}{2.8} \\
\hline & writing skills & $\%$ & 9.2 & 13.3 & 40 & 20 & 17.5 & \\
\hline \multirow[t]{2}{*}{2} & In working with the writing tasks in the textbook, I am & $\mathrm{F}$ & 10 & 14 & 50 & 28 & 18 & \multirow[t]{2}{*}{2.73} \\
\hline & $\begin{array}{l}\text { expected to focus on meaning than form of the } \\
\text { language. }\end{array}$ & $\%$ & 8.3 & 11.7 & 41.7 & 23.3 & 15 & \\
\hline \multirow[t]{2}{*}{3} & The writing tasks in the textbook are appropriate to & $\mathrm{F}$ & 20 & 17 & 36 & 26 & 21 & \multirow[t]{2}{*}{2.9} \\
\hline & develop knowledge and skill of the language. & $\%$ & 16.7 & 14.2 & 30 & 21.7 & 17.5 & \\
\hline \multirow[t]{2}{*}{4} & Success in doing a writing task is measured by both & $\mathrm{F}$ & 12 & 14 & 54 & 24 & 16 & \multirow[t]{2}{*}{2.85} \\
\hline & how it has been done and what has been done. & $\%$ & 10 & 11.7 & 45 & 20 & 13.3 & \\
\hline \multirow[t]{2}{*}{5} & The writing tasks help me to plan for my writing. & $\mathrm{F}$ & 17 & 21 & 4 & 51 & 27 & \multirow[t]{2}{*}{2.58} \\
\hline & & $\%$ & 14.2 & 17.5 & 3.3 & 42.5 & 22.5 & \\
\hline \multirow[t]{2}{*}{6} & Success in learning writing depends on tasks that my & $\mathrm{F}$ & 9 & 11 & 23 & 61 & 16 & \multirow[t]{2}{*}{2.47} \\
\hline & classmates and I do in the classroom. & $\%$ & 7.5 & 9.2 & 19.2 & 50.8 & 13.3 & \\
\hline \multirow[t]{3}{*}{7} & A task in the textbook can have different answers; this & $\mathrm{F}$ & 14 & 20 & 21 & 38 & 27 & \multirow[t]{2}{*}{2.63} \\
\hline & helps me to see the task in different perspectives. & $\%$ & 11.7 & 16.7 & 17.5 & 31.7 & 22.5 & \\
\hline & Grand Mean & & & & & & & 2.71 \\
\hline
\end{tabular}

Key: $\mathrm{f}=$ frequency, $\mathrm{SV}=$ Scale Values, $\mathrm{SA}=$ Strongly agree, $\mathrm{A}=$ Agree, $\mathrm{U}=$ Undecided, $\mathrm{D}=\mathrm{Disagree}, \mathrm{SD}=$ Strongly disagree.

The responses in table 1 above show that a few (20\%) of the respondents agreed that in working with the writing tasks they are expected to focus more on meaning than form of the language whereas the majority of the respondents did not focus on meaning (item 2). However, according to Bygate (2003), a task is an activity which requires learners to use language, with emphasis on meaning.

Similarly, the majority of the students $(54.2 \%)$ disagreed that the writing task in the textbook can have different answers and can help see the task in different perspectives (item 7). But Richards and Rodgers (2001: 228) suggest that 'tasks are believed to foster processes of negotiation, modification, rephrasing, and experimentation in second language learning.' In addition, Kumaravadivelu (1993) pointed out that writing tasks incorporate negotiation of meaning from different perspectives such as learning-centered procedures, communicative activities (learner-centered procedures) and structural exercises (language-centered procedures). Accordingly, the opportunity to modify the answers to a task is the way in which interaction contributes to language learning.

Regarding the role of tasks in facilitating learning, about $40 \%$ of the students did not decide whether or not tasks help them to improve their writing (item 1). In relation to this, the results of students' response in table 1 above show that a few $(31.7 \%)$ of the students agreed that the writing tasks helped them to plan for their writing whereas the majority of the students (65\%) showed their disagreement on the issue (item 5).

This shows that the students are not sure whether or not the writing tasks help them improve their writing ability and as it can be understood from the grand mean (2.71) which is below the average mean), they are found to have unfavorable perceptions about the effects of writing tasks on the improvement of their writing ability. 
Theme two: Perceptions concerning the relevance of writing tasks

Table 2: Students' responses about their perceptions concerning the relevance of writing tasks

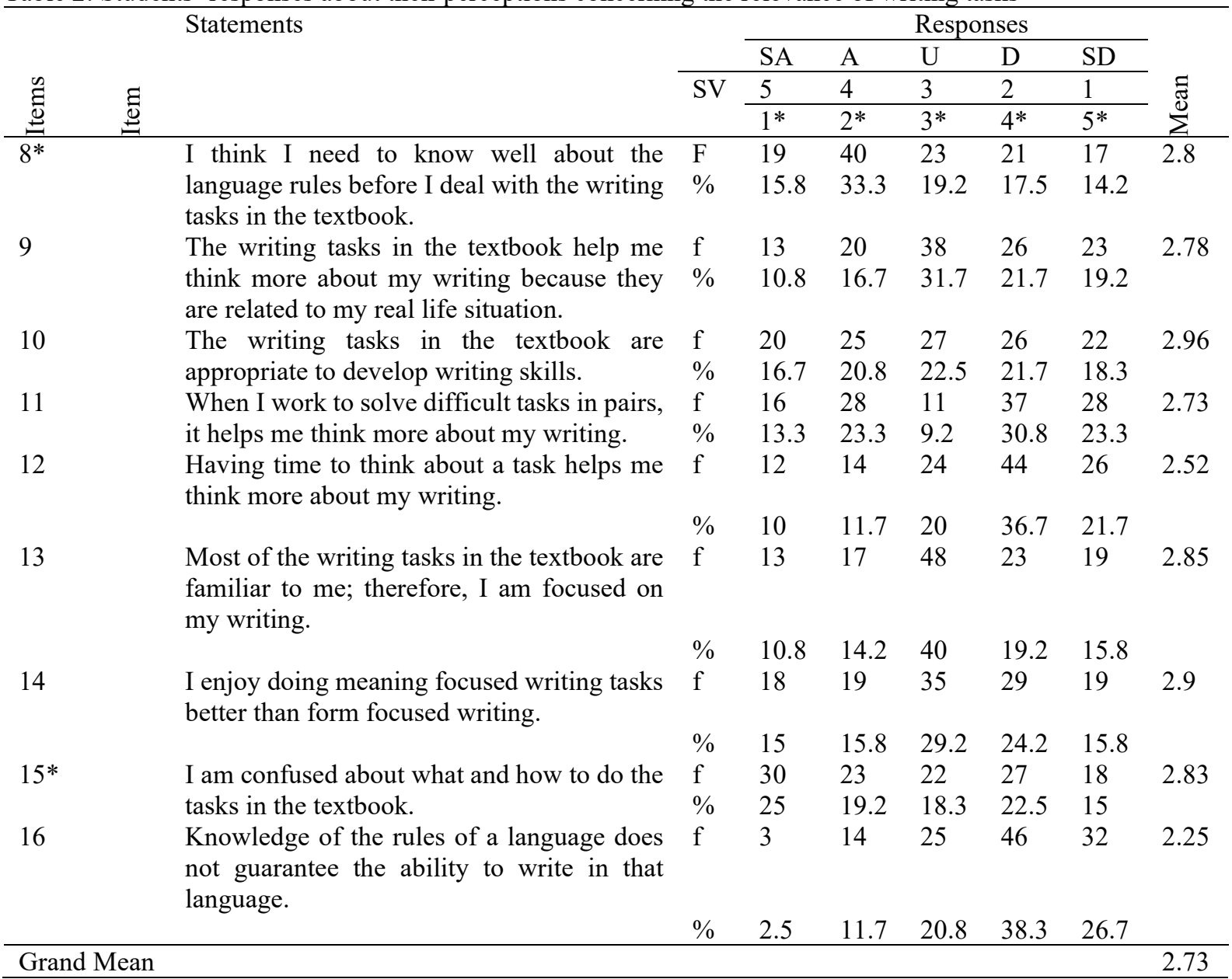

Key: $*=$ Unfavorable items and scale values, $\mathrm{SV}=$ Scale values, $\mathrm{f}=$ frequency, $\mathrm{SA}=$ Strongly agree, $\mathrm{A}=\mathrm{Agree}$, $\mathrm{U}=$ Undecided, $\mathrm{D}=$ Disagree, $\mathrm{SD}=$ Strongly disagree

As it can be seen in the above table nearly half of the students (49.1\%) agreed that they need to know well about the rules of the language before they deal with the writing tasks while $19.2 \%, 17.5 \%$ and $14.2 \%$ of them replied 'undecided', 'disagree' and 'strongly disagree' respectively (item 8). This indicates that as far as the students' perception is concerned, the language forms should be taught before they engage in the actual writing activity which is not compatible with the principles of TBW. In connection with item 9 and 10, many of the respondents (40.9\% and 40\%) disagreed on the supportiveness and appropriateness of the writing tasks in developing their writing skill whereas a considerable number of students $(31.7 \%$ and $22.5 \%)$ replied 'undecided' respectively. In addition, many $(54.1 \%)$ of the students disagreed that having time to think about a task helps them think more about their writing (item 12).

These indicate that the students' learning of writing seems to depend more on the teacher and this can also be understood from the response of item 11 in table 2. Moreover, as shown in the above table, one can understand the fact that the students' primal focus is on the rules of the language but not on meaning (items 13, 14, 15 and 16). 
Theme three: Perceptions concerning students' and teachers' roles in the writing tasks.

Table 3: Students' responses about their perceptions concerning students' and teachers' roles in the writing tasks.

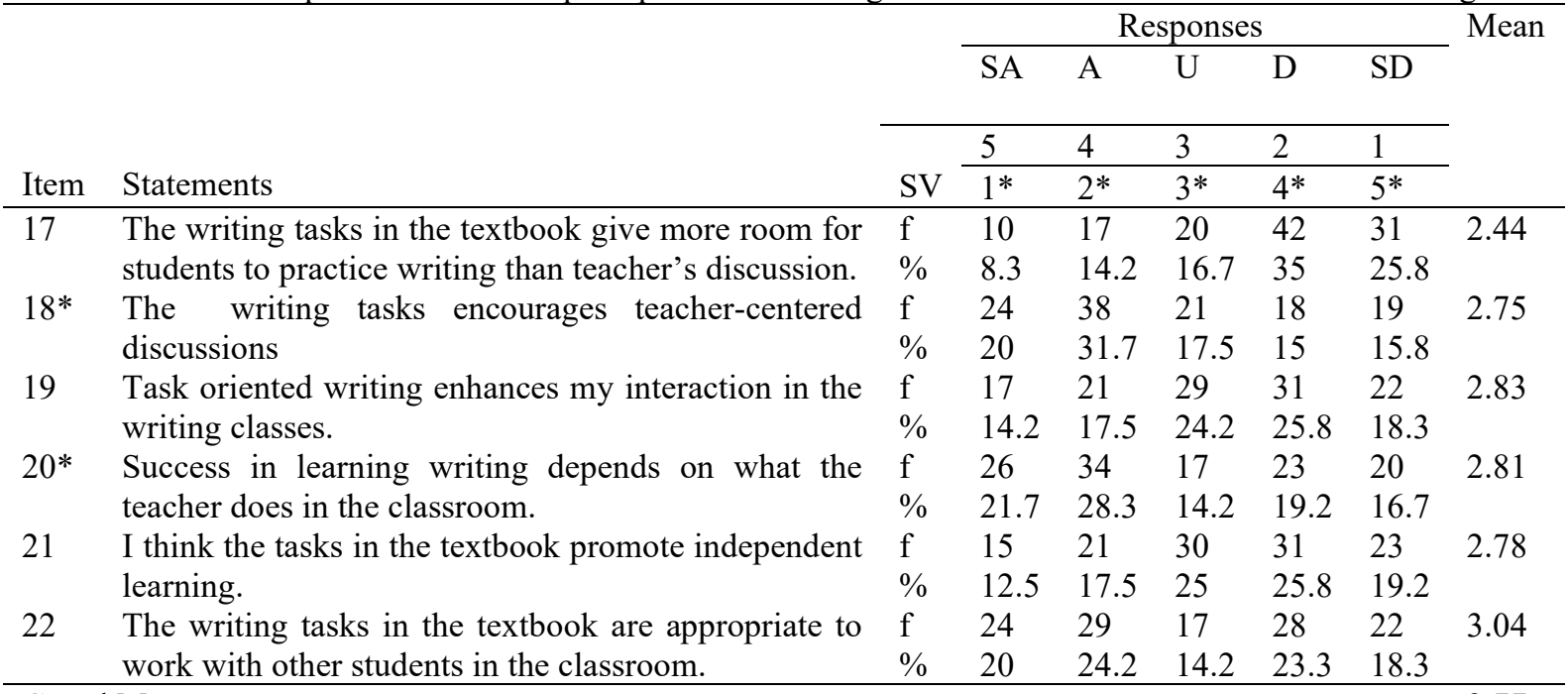

Grand Mean

2.77

Key: $*=$ Unfavorable items and scale values, $\mathrm{f}=$ frequency, $\mathrm{SV}=$ Scale values, $\mathrm{SA}=$ Strongly agree, $\mathrm{A}=\mathrm{Agree}$, $\mathrm{U}=$ Undecided, $\mathrm{D}=$ Disagree, $\mathrm{SD}=$ Strongly disagree

Students can contribute a lot to their writing skill when they are actively involved in performing the writing tasks. However, in the above table, many of the students $(60.8 \%)$ disagreed on the idea that the writing tasks give more opportunities to the learners than the teacher (Item 17).

In relation to this, half of the respondents agreed that success in learning to write depends on what the teacher does in the classroom whereas a few students (14.7\%) answered 'undecided' (item 20). But Ellis (2003: 176) stated that learning is not so much a matter of taking in and possessing of knowledge but rather of the taking part in activities. This indicates that the students' perceptions towards the writing tasks are incompatible with the modern principles TBLT

In addition, more than half of the students (51.7\%) agreed that the writing tasks encourage teacher-centered discussions than the students (item 18). Unquestionably, teachers' involvement in the teaching process, unless it distracts students learning, is essential for initiating learning activities, setting standards, assessing performances, and providing some forms of feedback. However, Stevick (1996) writes "the more the teacher talks and explains the less internal work the learner is likely to do". In contradiction with the principles of task based learning, about $45 \%$ of the students do not agree that the writing tasks promote independent learning (item 21). 
3.1.2. Results and Discussion of Students' Questionnaire for Practice

Table 4: Students' responses about their practices of writing tasks

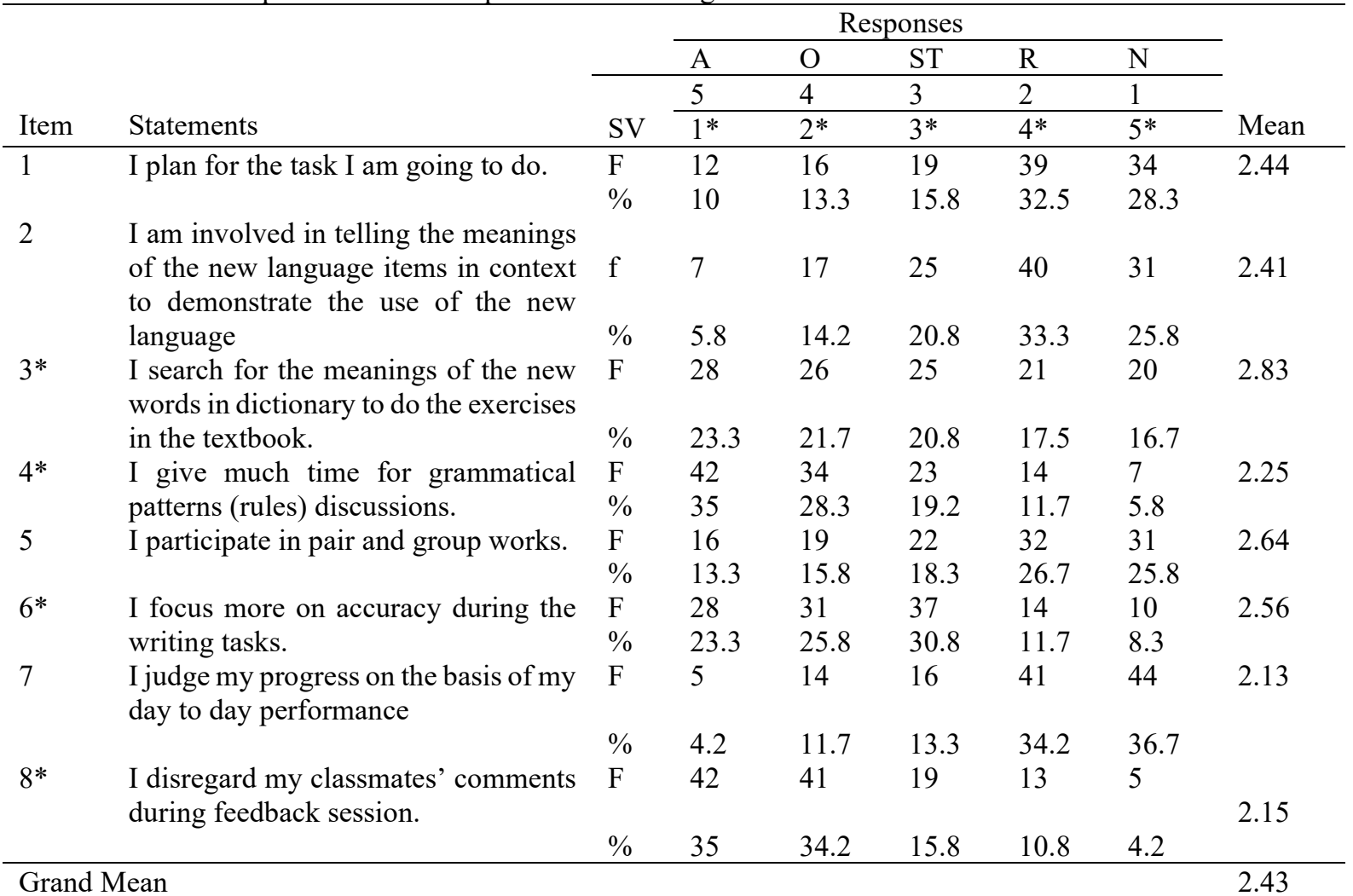

Key: * = Unfavorable items and scale values, $\mathrm{f}=$ frequency, $\mathrm{SV}=$ Scale values, $\mathrm{SA}=$ Strongly agree, $\mathrm{A}=$ Agree, $\mathrm{U}=$ Undecided, $\mathrm{D}=$ Disagree, $\mathrm{SD}=$ Strongly disagree

As depicted in table 4 , only $10 \%, 13.3 \%$ and $15.8 \%$ of the students stated that they plan for the tasks they are to do (item 1) 'always', 'often' and 'sometimes' while the rest students $(32.5 \%$ and $28.3 \%)$ replied 'rarely' and 'never' respectively. Similarly, most of the respondents $(20.8 \%, 33.3 \%$ and $25.8 \%)$ indicated that they 'sometimes', rarely' and 'never' involve themselves in finding contextual meaning of the language item they are using in their writing respectively (item 2). The results of items 1 and 2 indicate that most of the students depend on their teachers in finding the meanings of new words in the writing exercises and thus, much of the class discussion is dominated by the teachers.

Regarding their practice of writing, $23.3 \%, 25.8 \%$ and $30.8 \%$ of the students indicated that they focus more on accuracy than fluency (item 6), 'always', 'often' and 'some times' respectively. Similarly, 35\%, 28.3\% and $19.2 \%$ of the students replied that they 'always', often, and sometimes give much time for the grammatical patterns of the language respectively (item 4). This fits with the product approach of teaching and learning writing which advocates the structural linguists' view that gives primary emphasis for accuracy than fluency (Richards and Rodgers, 2001). This shows that most of the students give much of their time to learn about the forms of the language.

In response to questions asked to find out their efforts for cooperative learning, $13.3 \%, 15.8 \%$ and $18.3 \%$ of the students reported that they 'always,' often' and 'sometimes participate in pair and group works respectively (item 5). In relation to this, $45 \%, 34 \%$ and $15.8 \%$ of the students disclosed that they 'always' 'often' and 'sometimes' disregard their classmates' comments during the writing classes (item 8 ) respectively. These show that the students' habit of cooperative and collaborative learning is found to be insignificant. To conclude, data generated from the students' classroom practice generally revealed that they depend more on their teachers' contributions in their learning; and they preferred teachers-fronted discussions.

\subsection{Results and Discussion of the Teachers' questionnaire}

The objective of the questionnaire was to divulge the teachers' perceptions and practices of the writing tasks. The questionnaire consists of two sections with a total of 27 items. In section one, 19 items which were designed to identify teachers' perceptions of the writing tasks were given numerical scores with five point Likert scale ranging from 'strongly agree' to 'strongly disagree'. Similarly, in section two, 8 items which were developed to identify teachers' actual classroom practices of writing tasks were given five point Likert scale ranging from 'always' to 'never'. In this way, the data obtained from the numerical values of the five point Likert-type scales were put into 
a table under each theme using frequencies, percentages and mean.

\subsubsection{Results and Discussion of Teachers' Questionnaire for Perception}

Theme one: Perceptions concerning the effects of writing tasks on improving teaching or learning of writing. Table 5: Teachers' responses about their perceptions concerning the effects of writing tasks on improving the teaching and/ or learning of writing.

\begin{tabular}{|c|c|c|c|c|c|c|c|c|}
\hline \multirow[b]{4}{*}{ Item } & \multirow[b]{4}{*}{ Statements } & & \multicolumn{5}{|c|}{ Responses } & \multirow[b]{4}{*}{ Mean } \\
\hline & & \multirow[b]{3}{*}{ SV } & SA & A & $\mathrm{U}$ & $\mathrm{D}$ & SD & \\
\hline & & & 5 & 4 & 3 & 2 & 1 & \\
\hline & & & $1^{*}$ & $2 *$ & $3 *$ & $4 *$ & $5 *$ & \\
\hline \multirow[t]{2}{*}{1} & $\begin{array}{l}\text { The writing tasks in the textbook engage students to } \\
\text { put a primary focus on meaning. }\end{array}$ & $\mathrm{f}$ & 3 & 6 & 5 & 3 & 1 & 3.38 \\
\hline & & $\%$ & 16.7 & 33.3 & 27.8 & 16.7 & 5.6 & \\
\hline \multirow[t]{2}{*}{2} & $\begin{array}{l}\text { Students are expected to come up with clearly defined } \\
\text { outcomes at the end of their writings. }\end{array}$ & $\mathrm{f}$ & 3 & 6 & 5 & 3 & 1 & 3.38 \\
\hline & & $\%$ & 16.7 & 33.3 & 27.8 & 16.7 & 5.6 & \\
\hline \multirow[t]{2}{*}{3} & $\begin{array}{l}\text { The writing tasks promote learners' ability in } \\
\text { academic writing. }\end{array}$ & $\mathrm{f}$ & 3 & 8 & 4 & 3 & 0 & 3.6 \\
\hline & & $\%$ & 16.7 & 44.4 & 22.2 & 16.7 & 0 & \\
\hline \multirow[t]{2}{*}{$4 *$} & $\begin{array}{l}\text { The writing tasks in the textbook are beyond the } \\
\text { students' ability and therefore are difficult to teach. }\end{array}$ & $\mathrm{f}$ & 3 & 4 & 2 & 7 & 2 & 3.06 \\
\hline & & $\%$ & 16.7 & 22.2 & 11.1 & 38.9 & 11.1 & \\
\hline \multirow[t]{2}{*}{$5^{*}$} & $\begin{array}{l}\text { Pattern practices are more appropriate to provide } \\
\text { students meaningful context to use the target language } \\
\text { for writing. }\end{array}$ & $\mathrm{f}$ & 0 & 6 & 5 & 6 & 1 & 3.11 \\
\hline & & $\%$ & 0 & 33.3 & 27.8 & 33.3 & 5.6 & \\
\hline \multirow[t]{2}{*}{$6^{*}$} & $\begin{array}{l}\text { The end result of the writing task has to be assessed } \\
\text { by what the students have done rather than how they } \\
\text { have done it. }\end{array}$ & $\mathrm{f}$ & 1 & 6 & 5 & 3 & 3 & 3.06 \\
\hline & & $\%$ & 5.6 & 33.3 & 27.8 & 16.7 & 16.7 & \\
\hline \multirow[t]{2}{*}{7} & The outcomes of writing tasks are to be measured by & $\mathrm{f}$ & 2 & 4 & 6 & 4 & 2 & 3.0 \\
\hline & & $\%$ & 11.1 & 22.2 & 33.3 & 22.2 & 11.1 & \\
\hline
\end{tabular}

Key: $*=$ Unfavorable items and values, $\mathrm{f}=$ frequency, $\mathrm{SV}=$ Scale values, $\mathrm{SA},=$ Strongly agree $,=\mathrm{A},=$ Agree,$=$ $\mathrm{U}=$ Undecided, $\mathrm{D},=$ Disagree, $=\mathrm{SD}=$ Strongly disagree

As can be seen in table 5 above, about half of the respondents (16.7\% and $33.7 \%)$ reported 'strongly agree' and 'agree' respectively that the writing tasks in the textbook engage students to put primary focus on meaning than form whereas $16.7 \%$ and $5.6 \%$ of them were 'disagreed' and strongly 'disagreed' respectively (item 1). In connection with this, Nunan (2004) states that TBLT aims at providing learners with opportunities to experiment and explore both language through learning activities which are designed to engage learners in the authentic, practical and functional use of language for meaningful purpose. Learners are encouraged to activate and use whatever language they already have in the process of completing the task and the role of TBLT is to stimulate a natural desire in learners to improve their language competence by challenging them to complete meaningful tasks. Similarly, teachers' responses show that in task-based writing, language is primarily a means of making meaning.

Teachers' expectations of the final product of writing are likely to affect their students' focus on the writing activity. With regarded to the outcomes of the writing tasks, half of the teachers $(50 \%)$ agreed that students are expected to come up with clearly defined outcomes at the end of their writing whereas $27.8 \%, 16.7 \%$ and $5.6 \%$ reported 'undecided', 'disagree' and 'strongly disagree' respectively(item 2). Here, it is useful to distinguish the difference between the 'outcome' and the 'aim' of task. 'Outcome' refers to what the learners arrive at when they have completed the task. On the other hand, 'aim' refers to the pedagogic purpose of the task, which is to elicit meaning focused language. Indeed, it has been argued that it is not task features themselves but rather learner interpretation of task features which determine interactional outcomes (Breen 1987).

Though nearly half of the teachers seem to have an understanding of the theory of task based language teaching in general and the writing tasks in particular, $(33.3 \%)$ of the teachers agreed that pattern practice provides a meaningful context to use the target language for writing and other $38.9 \%$ respondents replied disagree (item 5). From this, it can be understood that although the teachers' perception about writing tasks is about average level, there are teachers who focuses on grammatical structures of the language. 
In response to item 6 , a considerable number of the respondents $(38.9 \%)$ concurred that the end result of the writing task has to be assessed by what the students have done rather than how they have done it while $27.8 \%$ and $33.4 \%$ replied 'undecided' and disagree. But on the other hand, 33.3\% of the teachers believed that an accomplishment of a task has to be evaluated more by the process in which the students did the task than the end result of the task (item 7). But it should be noted that, in the teaching learning process, what the students do in the task is as important as how they do the task. A task seeks to engage students in using language pragmatically rather than displaying language. In general, the responses obtained from the teachers' questionnaire show teachers' average understanding of the theoretical principles of teaching and learning writing.

Theme two: Perceptions concerning the relevance of writing tasks

Table 6: Teachers' responses about their perceptions concerning the relevance of writing tasks

\begin{tabular}{|c|c|c|c|c|c|c|c|c|}
\hline \multirow[b]{4}{*}{ Item } & \multirow[b]{4}{*}{ Statements } & & \multicolumn{5}{|c|}{ Responses } & \multirow[b]{4}{*}{ Mean } \\
\hline & & \multirow[b]{3}{*}{ SV } & SA & $\mathrm{A}$ & $\mathrm{U}$ & $\mathrm{D}$ & SD & \\
\hline & & & 5 & 4 & 3 & 2 & 1 & \\
\hline & & & $1 *$ & $2 *$ & $3 *$ & $4 *$ & $5 *$ & \\
\hline \multirow[t]{2}{*}{8} & The writing tasks help the students to & $\mathrm{F}$ & 1 & 6 & 4 & 6 & 1 & 3.0 \\
\hline & & $\%$ & 5.6 & 33.3 & 22.2 & 33.3 & 5.6 & \\
\hline \multirow[t]{2}{*}{9} & The writing tasks in the textbook are & $\mathrm{F}$ & 2 & 5 & 5 & 6 & 0 & 3.17 \\
\hline & & $\%$ & 11.1 & 27.8 & 27.8 & 33.3 & 0 & \\
\hline \multirow[t]{2}{*}{10} & The writing tasks help students to plan & $\mathrm{F}$ & 3 & 6 & 5 & 4 & 0 & 3.44 \\
\hline & & $\%$ & 16.7 & 33.3 & 27.8 & 22.2 & 0 & \\
\hline \multirow[t]{2}{*}{11} & The writing tasks improve learners' & $\mathrm{F}$ & 1 & 7 & 3 & 6 & 1 & 3.06 \\
\hline & interaction skills. & $\%$ & 5.6 & 38.9 & 16.7 & 33.3 & 5.6 & \\
\hline \multirow[t]{2}{*}{12} & $\begin{array}{l}\text { The writing tasks help students to } \\
\text { focus on real world activities. }\end{array}$ & $\mathrm{F}$ & 2 & 6 & 3 & 5 & 2 & 3.06 \\
\hline & & $\%$ & 11.1 & 33.3 & 16.7 & 27.8 & 11.1 & \\
\hline \multirow[t]{2}{*}{13} & It is essential to use task based & $\mathrm{F}$ & 3 & 6 & 1 & 4 & & 3.0 \\
\hline & teaching in the writing classes. & $\%$ & 16.7 & 33.3 & 5.6 & 22.2 & 22.2 & \\
\hline \multirow[t]{2}{*}{$14 *$} & It is more important for students to & $\mathrm{F}$ & 2 & 4 & 2 & 5 & 5 & 3.39 \\
\hline & & $\%$ & 11.1 & 22.2 & 11.1 & 27.8 & 27.8 & \\
\hline
\end{tabular}

Key: $*=$ Unfavorable items and values, $\mathrm{f}=$, frequency, $\mathrm{SV}=$ Scale values, $\mathrm{SA}=$ Strongly agree, $\mathrm{A}=\mathrm{Agree}, \mathrm{U}=$ Undecided, $\mathrm{D}=$ Disagree, $\mathrm{SD}=$ Strongly disagree.

As shown in table 6 above, $50 \%$ of the teachers indicated that it is essential to use tasks in their writing classes (item 13) because the tasks help the students to use the target language outside the classroom whereas the rest $44 \%$ of the respondents answered that it is difficult to use task based teaching in the writing classes and the remaining $5.6 \%$ of them replied 'undecided' (item 13).

In relation to this, Willis (1996) indicates that task based teaching as a method is challenging when the teacher and the students do not have orientations about the method; as a result, students' participations will be limited.

In response to item $14,55.6 \%$ of the teachers disagreed to the statement "It is more important for students to learn rules of the language than its use in the writing classes" which is in agreement with what Ellis (2003) stated that in task based language teaching, there is naturally less concern for use of grammatical accuracy. That is to say, working more on grammatical accuracy inhibits students learning of writing.

With regard to the contribution of writing tasks in improving students interaction skill, $44.5 \%$ of the teachers believed that the writing tasks in the textbook improve students' pair or group interaction skills whereas $16.7 \%$, $33.3 \%$ and $5.6 \%$ of them replied 'undecided', 'disagree' and 'strongly disagree' respectively (item 11 ). Interaction is a pivotal element of the task based teaching which is student-centered. Therefore, this indicates that teachers' perception about the significance of writing tasks in improving writing skill is found to be moderate with a mean score of 3.39. Generally, it can be understood from the grand mean (3.16) of the above table that teachers have positive perceptions about the relevance of writing tasks in the items posed to find out their perceptions. 
Theme three: Perceptions concerning students' and teachers' roles in the writing tasks.

Table7: Teachers' responses about perceptions concerning students' and teachers' roles in the writing tasks.

\begin{tabular}{|c|c|c|c|c|c|c|c|c|}
\hline \multirow[b]{4}{*}{ Item } & \multirow[b]{4}{*}{ Statements } & \multicolumn{6}{|c|}{ Responses } & \multirow[b]{4}{*}{ Mean } \\
\hline & & & SA & A & $\mathrm{U}$ & D & SD & \\
\hline & & \multirow[b]{2}{*}{ SV } & 5 & 4 & 3 & 2 & 1 & \\
\hline & & & $1 *$ & $2 *$ & $3 *$ & $4 *$ & 5* & \\
\hline \multirow[t]{2}{*}{15} & \multirow{2}{*}{$\begin{array}{l}\text { The writing tasks are based on the } \\
\text { student-centered instructional } \\
\text { approach. }\end{array}$} & $\mathrm{F}$ & 0 & 5 & 4 & 6 & 3 & 2.61 \\
\hline & & $\%$ & 0 & 27.8 & 22.2 & 33.3 & 16.7 & \\
\hline \multirow[t]{2}{*}{$16^{*}$} & \multirow{2}{*}{$\begin{array}{l}\text { Success in teaching writing } \\
\text { depends more on what the teacher } \\
\text { teaches. }\end{array}$} & $\mathrm{F}$ & 3 & 5 & 2 & 5 & 3 & 3.0 \\
\hline & & $\%$ & 16.7 & 27.8 & 11.1 & 27.8 & 16.7 & \\
\hline \multirow[t]{2}{*}{$17 *$} & \multirow{2}{*}{$\begin{array}{l}\text { The writing tasks put much burden } \\
\text { on the teacher. }\end{array}$} & $\mathrm{F}$ & 7 & 3 & 3 & 3 & 2 & \multirow[t]{2}{*}{2.44} \\
\hline & & $\%$ & 38.9 & 16.7 & 16.7 & 16.7 & 11.1 & \\
\hline \multirow[t]{2}{*}{$18^{*}$} & Most students do not have interest & $\mathrm{F}$ & 4 & 7 & 1 & 4 & 2 & \multirow[t]{2}{*}{2.61} \\
\hline & activity. & $\%$ & 22.2 & 38.9 & 5.6 & 22.2 & 11.1 & \\
\hline \multirow[t]{2}{*}{$19^{*}$} & If the teacher do not explain an & $\mathrm{F}$ & 3 & 7 & 2 & 4 & 2 & \multirow[t]{2}{*}{2.72} \\
\hline & students will waste their time. & $\%$ & 16.7 & 38.9 & 11.1 & 22.2 & 11.1 & \\
\hline
\end{tabular}

Key: $*=$ Unfavorable items and values, $\mathrm{f}=$ frequency, $\mathrm{SV}=$ Scale values, $\mathrm{SD}=$ Strongly agree, $\mathrm{A}=\mathrm{Agree}, \mathrm{U}=$ Undecided, $\mathrm{D}=$ Disagree, $\mathrm{SD}=$ Strongly decided

As made known in table 7 above, $44.5 \%$ of the teachers agreed that success in teaching writing depends more on what the teachers teach (item 16). But in contradiction with this, $44.4 \%$ of the respondents revealed that they did not agree with the statement about teacher dominated writing activities. In association with this point, more than half of the teachers $(55.6 \%)$ agreed that it is appropriate for the teachers to explain an activity thoroughly first, so that the students can effectively use their time while other $33.3 \%$ of the respondents disagreed about the issue (item 19). The paradox is if the teachers use much of the time for explanation, students are left with little time to actively participate in accomplishing tasks in the classroom.

As far as students' participation is concerned, $61 \%$ of the teachers disclosed that most students are reluctant to participate in the writing activities whereas only $33.3 \%$ of them stated that the students are interested to participate in writing tasks (item 18). In principle, effective learning is a result of greater self-direction rather than dependence up on the teacher. In response to item 17, 55.6\% of the teachers agreed that the writing tasks put much burden on them (item 19) that is in conflict with the principle of task-based instruction which should not be teachercentered.

Therefore, it requires commitment on the part of the teachers to help students to participate in the writing classes. If students are notably lacking in these qualities of taking part in the writing tasks, task-based instruction may indeed be difficult to put into practice (Atkinson, 2003). In general, most of the teachers favored more on the role of themselves in teaching than students' role in learning.

\subsubsection{Results and Discussion of Teachers' Questionnaire for Practice}

This questionnaire was mainly used in order to find out what the teachers were to say about their actual classroom practices of the writing tasks. The results of teachers' responses were presented in the table below. 
Table 8: Teachers' responses about their practices of TBW

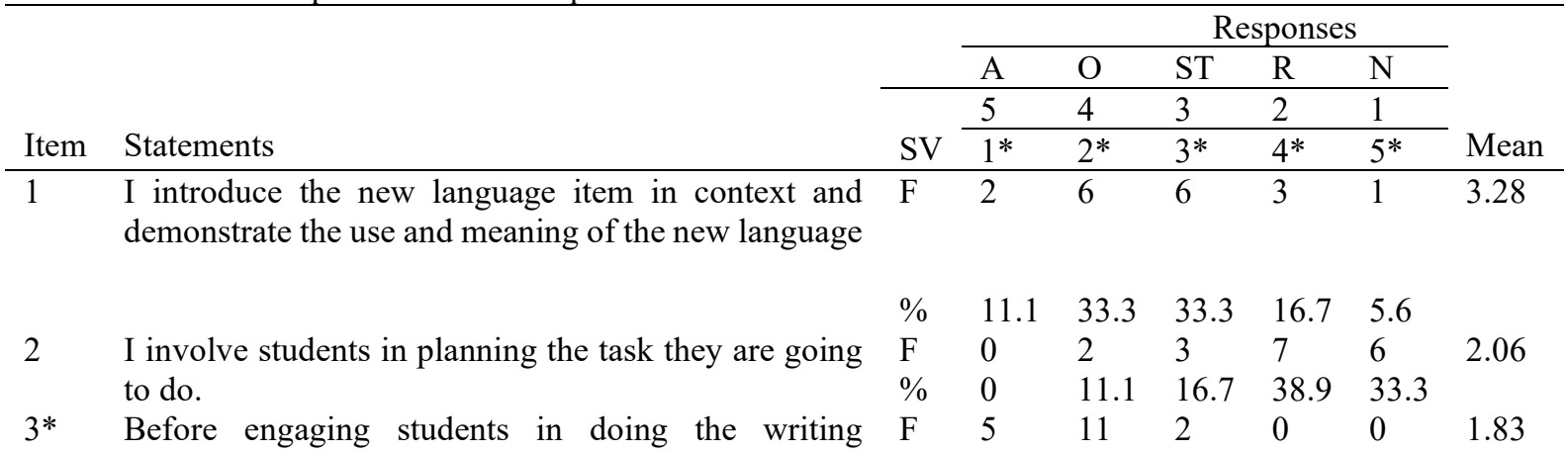
exercises, I explain new grammatical terminologies or forms and patterns (rules). tor

4 I encourage and involve students to find the contextual meaning of the new language items.

$5 \quad$ I involve students in pair and group works. 6 I help students to correct their error in pair and group
discussion.

7* I correct students' error in controlled practice activities like question and answer.

8 I evaluate students' progress on the basis of their day to day communicative performance.

\begin{tabular}{lllllll}
$\%$ & 27.8 & 61.1 & 11.1 & 0 & 0 & \\
$\mathrm{~F}$ & 1 & 5 & 3 & 6 & 3 & 2.72 \\
& & & & & & \\
$\%$ & 5.6 & 27.8 & 16.7 & 33.3 & 16.7 & \\
$\mathrm{~F}$ & 2 & 5 & 3 & 4 & 4 & 2.83 \\
$\%$ & 11.1 & 27.8 & 16.7 & 22.2 & 22.2 & \\
$\mathrm{~F}$ & 3 & 4 & 2 & 6 & 3 & 2.89 \\
& & & & & & \\
$\%$ & 16.7 & 22.2 & 11.1 & 33.3 & 16.7 & \\
$\mathrm{~F}$ & 6 & 8 & 1 & 3 & 0 & 2.06 \\
& & & & & & \\
$\%$ & 33.3 & 44.4 & 5.6 & 16.7 & 0 & \\
$\mathrm{~F}$ & 2 & 4 & 0 & 6 & 6 & 2.44 \\
& & & & & & \\
$\%$ & 11.1 & 22.2 & 0 & 33.3 & 33.3 & \\
\hline
\end{tabular}

Grand mean

Key $=*=$ Unfavorable items and values, $\mathrm{f}=$ frequency, $\mathrm{SV}=$ Scale values, $\mathrm{SA}=$ Strongly agree, $\mathrm{A}=\mathrm{Agree}, \mathrm{U}=$ Undecided, $\mathrm{D}=$ Disagree, $\mathrm{SD}=$ Strongly disagree

From the above table (table 8 ), it can be understood that most of the teachers $(27.8 \%$ and $61.1 \%)$ responded that before engaging students in doing the writing tasks, they 'always' and 'often' explain new grammatical terminologies or forms respectively while just $11.1 \%$ of them said 'sometimes' (item 3).

Contrary to the principles of TBLT in general TBW in particular, only $5.6 \%$ and $27.8 \%$ of the teachers replied that they 'always' and 'often' encourage and involve students in finding the contextual meaning of the new language items (item 4). But on the other hand, half of the respondents (50\%) answered that they 'rarely and 'never' encourage the students to find out the contextual meaning of new language items. This implies that the majority of the class activities were done through information transmission or teachers-centered approach.

In responses to item 7, a dominating proportion of the teachers (33.3\% and $44 \%)$ pointed out that they 'always' and 'often correct students' error in controlled practice activities correspondingly whereas only a few (16.7\%) of them replied 'rarely' and none of them said 'never'. In line with this point, a few of the teachers $(11.1 \%$ and $22.2 \%)$ responded that they 'always' and 'often' evaluate students' progress on the basis of their day to day communicative performance and the remaining $66.6 \%$ of them responded 'rarely' and 'never' in combination (item 8 ). In addition, as it can be seen in item 6 , half of the teachers $(50 \%)$ revealed that they 'rarely' and 'never' made students correct errors in pairs and groups whereas $16.7 \%, 22.2 \%$ and $11.1 \%$ of them disclosed that they 'always', 'often' and 'sometimes help students to correct errors in pairs and groups respectively. Moreover, for item 5, 44.4\% of the teachers said that they 'rarely' and 'never' involve students in pair and group works while $11.1 \%$ and $27.8 \%$ of them replied they did 'always' and 'often' respectively. In short from the responses of the teachers for items 5 to 8 , it can be implied that the actual practices of teachers in teaching writing is predominantly teacher based and form focused which is in contradiction with the principles of TBLT in general and TBW in particular.

\subsection{Results and Discussion of Students' Interview}

An interview with six items on 12 students who were selected from the sample representatives was made to find out about their perceptions of the writing tasks. The interview is mainly aimed at crosschecking the trustworthiness and soundness of the data collected using the questionnaires about students' perceptions towards the writing tasks 
of the textbooks.

The interview result pointed out the fact that almost all students have wrong perceptions about the writing tasks. In addition, most respondents' indicated that the English language classroom instruction they have been experiencing is form-focused. As the researcher asked one of the students, if he could tell me anything about task and writing tasks, he said: “ ...to be honest I don't know what tasks are but I guess they are exercises to be done in order to improve our knowledge of the language rules. I don't have experience about writing tasks. I am most of the time confused on how to work with tasks thus I prefer the teacher to show me how to work the tasks" (S1. $11 / 03 / 2018)$.

The student made clear that he perceived writing tasks as exercises that help him to improve his knowledge of grammatical structures of the language which is in contradiction with what they really are. As a result, he faced problems to assume a role in his writing class. Therefore, he expected that his teacher can help him a lot during the writing lessons. Similarly another student said, "Writing tasks are questions and answers about how to write and are good for sharing of ideas and answering questions. They are generally classroom participations about writing skill" (S2. 11/03/2018).

In connection with this, Nunan (2004) defines a 'task' as a piece of classroom work which involves learners in interacting in the target language while their focus of attention is entirely on meaning rather than on form.

In this regard, the students were found to have poor perceptions on what a task is which obviously result in their poor perceptions of the writing tasks of the textbooks as well. This is because they simply represent a task as no more than 'a question and answer' or classroom participations between their teacher and themselves.

However, according to Prabhu (1987) tasks should be viewed as process-oriented vehicles of language learning focusing on learner involvement and meaning. The data generally show that students have misunderstanding about what a task actually is which can obviously be taken as one major weaknesses of their teachers. That is why their definitions are mainly consisted of the two content words of 'questions' and 'answers'. This obviously may enforce students to focus on form than meaning.

The principle of task based writing emphasizes students' active involvements in the writing process. Regarding their roles in the writing tasks, most students seemed to have no clear idea. They are highly dependent on what their teachers teach them. Therefore, they value more their teachers' contributions in giving sample writings and feedback to the writing exercises than their own contributions. One of the students said, “....., I feel that the teacher is in the class to show me not only how to do the tasks but also all the things in the textbook and at the end give me answers to the tasks. So, the role of the teacher in my learning of writing is very crucial" (S3. $11 / 03 / 2018)$.

In the review of related literature, scholars like Nunan (2004) indicated that tasks enhance students learning. However, students' responses in relation with the contribution of writing tasks in enhancing their writing skill is not compatible with the real contributions writing tasks have in boosting students writing ability. And some students responded that they felt that the tasks inhibit their writing because the processes of doing tasks are complicated. One of the students said, "I really don't know whether or not tasks enhance my writing because I don't know the roles of task in my learning our teacher hardly give us such tasks" (S5. 11/03/2018).

From this, it is possible to say that learners were denied the opportunity to practice writing through tasks; and writing with task based approach. In general, the students' responses to the interview questions converge with what they reported in the questionnaire about the perceptions they hold on the writing tasks which is found to be unfavorable and incompatible with the basic theoretical principles of TBLT.

Thus, they seemed to have wrong insights about TBW in general and the writing tasks in particular, the roles of both teachers and students in accomplishing writing tasks and the remarkable contributions the writing tasks have in improving writing skill.

\subsection{Results and Discussion of Teachers' Interview}

An interview with seven items on six English teachers of grade 11 and 12 students was made to find out their perceptions towards the writing tasks of the textbooks. The interview mainly focused on crosschecking the reliability and validity of the data collected using the questionnaires about teachers' perceptions of the writing tasks. The interview questions include information about teachers' intuitions of the writing tasks, the effects of writing tasks in improving writing skill and the roles of both teachers' and students' in the writing tasks.

The teachers had the impression that students were unable to cope with the demands of the writing tasks. The reason, according to the teachers, is that students lacked experience in task-based learning. In connection with this the teachers said the following:

.... I have encountered problems such as students' inability of writing and lack of awareness about their own contribution in improving their writing. This in one way or another hindered them to work with tasks in the textbook because most students do not know how to work with the tasks. What is important here is that most students do not know what is expected of them in accomplishing the writing tasks in the textbook...... (T1. 12/03/2018). 
As a result, the teachers tended to maximize their roles in teaching writing. In addition, the teachers went on saying that, they are viewed as knowledge holders by their students. When they do not display their knowledge in lectures or if they organize and implement a great deal of group works in class, they may be regarded as "not doing their job"; and therefore can be criticized by the students. One of the teachers said:

"-----Students do not exactly know their roles and contributions in task-based teaching. To me the teacher is expected to facilitate the process but not working the whole part of the entire activities. But many of the students feel that the teacher is there to provide them with all the answers to the questions" (T2, 12/03/2018).

Since writing is the interaction between the writer and reader, students in the writing classes are expected to participate in the writing processes. If students are willing to participate and contribute in the writing classes, they can tell how much their writing is improved. One of the teachers said: "I think the writing tasks can play remarkable role in promoting student- centered approach but the problem is students are not clear about how to work on tasks" and they are not interested in cooperative and collaborative learning activities like pair and group works" (T2, 12/03/2018).

However, In support of cooperative learning, Hyland (2006) stated that collaborative learning encourages students to 'pool' their resources in order to complete tasks they could not do on their own. Besides, they assist them to be more competent and effective in writing skill as it creates an opportunity to crosscheck each other's' writings. Moreover, collaborative language learning helps to raise the achievement of students and to improve interaction in the actual classroom so that students can work and practice writing tasks together for communicative purpose (Richards and Rodger, 2001). Teacher 3 also explained that: “.... Since students are unable to write well, the writing activities are something not more than grammatical exercises for them. The students are rules seekers and hence the writing classes are teacher-dominated."

This is not in agreement with the notion of TBLT and student centered approach. This tendency of blaming students for their inability in writing and misunderstandings about the writing tasks will not bring change in improving their writing ability.

\subsection{Results and Discussion of the Classroom Observation}

3.5.1. Results and Discussion of Part One of the Classroom Observations

Table 9: Descriptive statistics (frequency, percentage and mean) of instructional activities

\begin{tabular}{|c|c|c|c|c|c|c|c|}
\hline \multirow[b]{4}{*}{ Items } & \multirow[b]{4}{*}{ Activities } & & \multicolumn{3}{|c|}{ Remarks } & \multirow[b]{4}{*}{ Total } & \multirow[b]{4}{*}{ Mean } \\
\hline & & \multirow{3}{*}{ SV } & \multicolumn{3}{|c|}{ E A } & & \\
\hline & & & 3 & 2 & 1 & & \\
\hline & & & & & & & \\
\hline 1 & Classroom $\quad$ activities $\quad$ maximize & $\mathrm{f}$ & 2 & 2 & 4 & 8 & 1.75 \\
\hline & $\begin{array}{l}\text { communication opportunities through interactions and } \\
\text { negotiation of meanings }\end{array}$ & & & & & & \\
\hline & & $\%$ & 25 & 25 & 50 & & \\
\hline 2 & Language forms are addressed within a communicative & f & 1 & 3 & 4 & 8 & 1.63 \\
\hline & context. & $\%$ & 12.5 & 37.5 & 50 & & \\
\hline 3 & learner-centered & f & 1 & 2 & 5 & 8 & 1.5 \\
\hline & & $\%$ & 12.5 & 25 & 62.5 & & \\
\hline 4 & Emphasis on meaning & $\mathrm{f}$ & 0 & 3 & 5 & 8 & 1.38 \\
\hline & & $\%$ & 0 & 37.5 & 62.5 & & \\
\hline 5 & Promote cooperative and Collaborative Learning & f & 0 & 4 & 4 & 8 & 1.5 \\
\hline & & $\%$ & 0 & 50 & 50 & & \\
\hline 6 & The steps of $\quad$ Writing & f & 1 & 4 & 3 & 8 & 1.75 \\
\hline & & $\%$ & 12.5 & 50 & 37.5 & & \\
\hline
\end{tabular}

Grand Mean
Key: $\mathrm{f}=$ frequency, $\mathrm{SV}=$ Scale values, $\mathrm{E}=$ Effectively, $\mathrm{A}=$ Averagely, $\mathrm{P}=$ Poorly

As observed and as it can be inferred from the above table, meaning focused and student-centered approaches were not implemented in most of the sections (62.5\%) (items 3 and 4). Teachers used much time in explaining grammatical aspects of the language rather than using the allotted time to teach writing skill appropriately. As a result, students could not get enough exposure to practice the writing activities in their real life communication. Teachers were observed focusing simply on teaching their students about the theoretical and grammatical aspects of the language like the definitions of words related to writing, in depth lecturing or explanation about the tenses used in writing story, the types of letters and the parts to be included, types of essays with their definitions and the likes rather than letting their students produce a piece of writing practically. Similarly, $50 \%$ of the sections were seen addressing language forms in isolation with communicative context whereas $37.5 \%$ and $12.5 \%$ of them were observed dealing with the language structures in context averagely and poorly respectively (item 2 ). 
In short, table 9 presents the fact that in real practice the students and teachers attached the least amount of importance to the representative tenets of TBLT in general and TBW in particular. For instance, when we look at the mean scores of the items in the above table, all of them are far below the average mean score (2) and therefore it is possible to say that the actual practices of both the teachers and students in teaching and learning writing tasks are found to be poor.

\subsubsection{Results and Discussion of Part Two of the Classroom Observations}

Table 10: Descriptive statistics (frequency, percentage and mean) of the roles both teachers and students play in each task phase

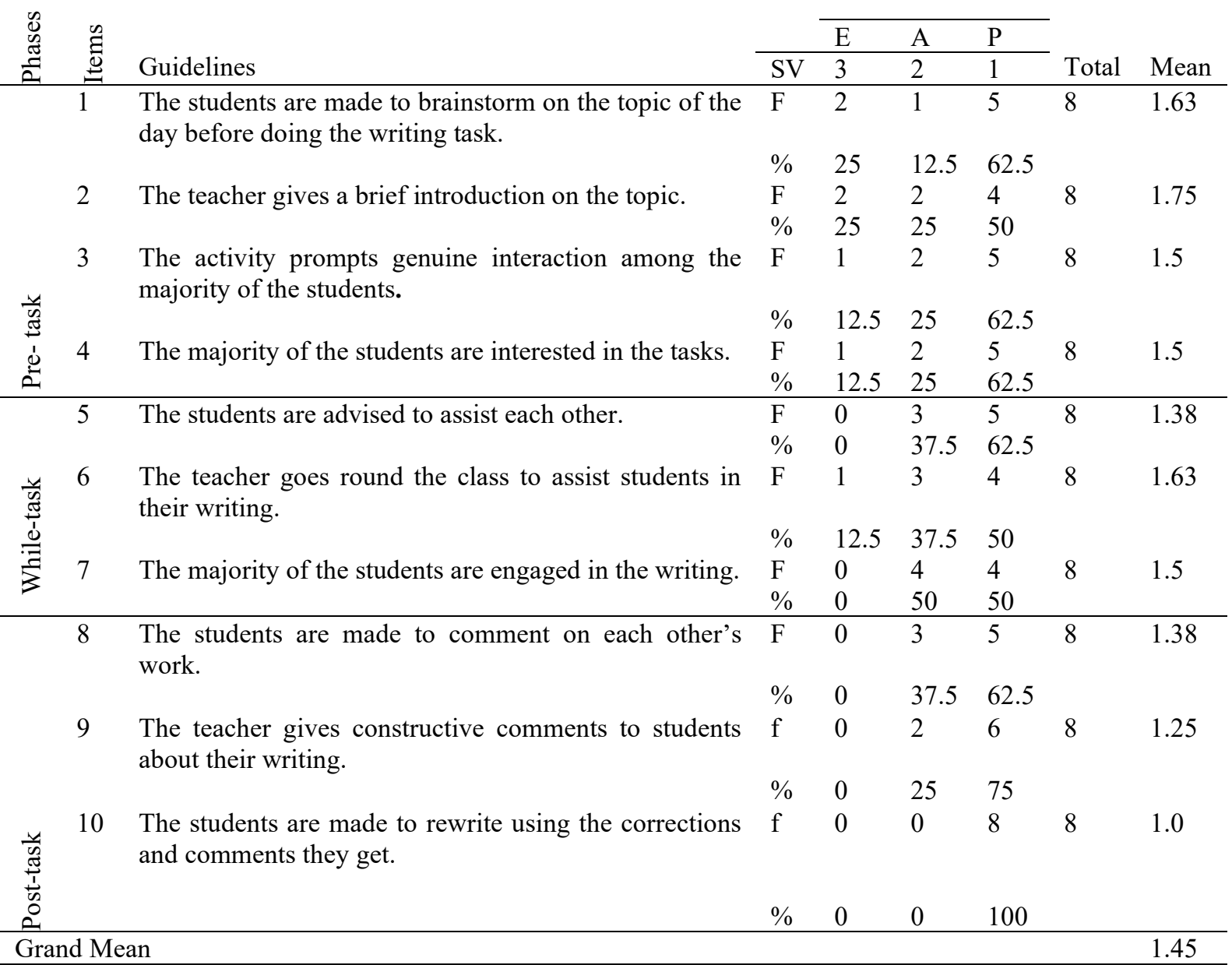

Key: $\mathrm{f}=$ frequency, $\mathrm{SV}=$ Scale values, $\mathrm{E}=$ Effectively, $\mathrm{A}=$ Averagely, $\mathrm{P}=$ Poorly

As it is depicted in the above table, the three phases of teaching and or learning writing were observed and recorded using the guideline as a checklist. The results of the observation in each phase were summarized in themes as follows.

\section{A. Pre-Task Phase}

As it was discussed in the review of literature section, this is the phase where teachers play their major roles in introducing the topic and help the students plan for the task they are going to do. In the observed eight sections too, all eight different teachers introduced and explained the topic. However, only three out of the eight teachers made the students to brainstorm on the topics before planning and doing the writing tasks while others went on directly to the explanation.

In response to item 3 and 4, the majority of the students in a few sections (1 and 2) were made to genuinely interact effectively and averagely correspondingly and they were also looked interested in the writing activities. But on the other hand, most of the students in the rest six $(62.5 \%)$ of the sections were observed simply gazing up on their teacher and were not involved in the writing tasks at all. From this, it can be understood that teachers play roles which are irrelevant for communicative classroom. They were expected to make students involve actively in the process. Students were required to brainstorm and discuss between and among each other. They were required to be made the major actors of the writing process. Therefore, in this pre-writing phase, the majority of the students were less interested in doing the writing tasks and less motivated in interacting with each other about the topics. 


\section{B. While writing Phase}

Only in four sections (see table 9, item 5), the students were made to plan their writing and were made to select a partner to work with and share the writing task between them whereas in the rest four sections, the students were not given time to practice the writing tasks. In connection with this, none of the teachers were observed advising students to assist each other and were monitoring their progress effectively while in three of the sections the teachers were observed telling students to share ideas indifferently (item 5).

In addition, some teachers were simply moving round the class by reminding the students not to disturb rather than assisting them (item 6).

As it was discussed in chapter two by Willis (1996), in this phase, teachers are required to encourage all students to actively participate in the process, making sure that all pairs or groups are doing the right task and are clear about the objectives, assist students in their difficulties and advise them to assist each other and go round the class so as to monitor the process. This is different from what the roles teachers play in the actual classroom practice of task based writing. Consequently, the students in four sections were not totally engaged in the writing tasks whereas in the other four sections, they were seen showing moderate or average engagement (item 7). Generally, in the while task phase too, the majority of the teachers and students were not playing their roles effectively.

\section{Post-Task Phase}

In this last phase as it was discussed in chapter two, teachers are required to give feedback for the task the students did at home or made the students comment on each other's work. Students on the other hand, are required to incorporate the feedbacks and rewrite their final draft. However, what was observed in all of the classes was different. None of the teachers made the students comment on each other's work nor made them rewrite using the corrections and comments effectively (item 8 and 10). In addition, none of the teachers were observed giving constructive comments to students about their writing effectively even though some of them were seen giving very general comments to one or two students as a sample (item 9).

By examining the above result, it can be said that like in previous phases, teachers in this phase too were not observed playing their role effectively. Besides, students also fail to play their role in peer feedback and corrections. Therefore, it can be said that in the observed eight sections, the writing sessions ended before the process of writing was completed.

\section{Conclusions and Recommendations}

\subsection{Conclusions}

Based on the discussion and the overall findings of the study, the following conclusions were made.

1. It has been proved in the study that students' perceptions about the effects of writing tasks in improving writing skill, the relevance of writing tasks and the roles both students and teachers should play in practicing the writing tasks have been unfavorable and in contradiction with the basic tenets of TBLT.

2. The students' contributions for the improvement of their own writing (table 3: item 17) and the importance of writing tasks in boosting the learners' writing ability (table 1: item 1) were not given a place by the students.

3. The findings of the students' questionnaire and the classroom observations pointed out that the actual classroom practices of the students in learning writing are far from the principles of TBW. The active engagement of the learners in the process of accomplishing writing activities was denied and basic principles like student-centeredness (table 9: item 3), and emphasis on meaning (table 9: item 4) were hardly practiced in the actual setting of learning writing.

4. In accomplishing the writing tasks, students should play remarkable roles in all three phases of writing. However, according to the results of classroom observations, most of the students did not go through these three phases properly and they were not observed playing the required roles in each phase of the writing tasks.

5. According to teachers' questionnaire and interview, theoretically, the majority of the teachers had reasonably positive perceptions about the very general nature of task and writing tasks specifically about the effects and relevance of writing tasks in improving students' writing ability. However, their perceptions about the roles of students and teachers were proved to be poor . The majority of the teachers did not clearly identify what roles the teachers themselves and their students should play in task based writing and this uncovered the fact that the teachers did not have an in-depth understanding about how the writing tasks are put into practice.

6. The responses of teachers in the interview disclosed the fact that teachers tended to conclude that most students were unable to participate in the writing task because of their inability to write. In addition, the teachers were complaining that students were not willing to take responsibility for their writing. However, an interesting experience drawn from the teachers' perceptions is a context dilemma. Teachers should not consider students' writing inability only as a constraint but also as an opportunity. Accordingly, they should help students to cope up with the demands of task-based writing.

7. The findings of both the teachers' questionnaire and classroom observations pointed out the fact that most of the teachers hardly gave importance to the representative tenets of TBW in their actual practices of teaching 
writing which is somewhat in contradiction with their conceptual understanding. Their practices of teaching writing are predominantly teacher-centered and form-focused. As a result, the roles both teachers and students should play in each phase of the writing tasks were not properly implemented.

\subsection{Recommendations}

Based on the findings and conclusions of the study, it is worthwhile to suggest the following recommendations.

1. Since teachers' perceptions and actual practices of the writing tasks undeniably have great impacts on students' writing ability, efforts should be exerted to make teachers well-aware about TBLT principles and to make them clear with how these principles can be practiced in the real classroom context. For the purpose of doing this, teacher educators, education bureaus and other concerned bodies should organize in-service training programs, workshops and seminars to English language teachers and these also enable them to get the chance of sharing experiences on how to cope with the existing problems.

2. The basic assumption of Task-Based Writing - that it provides for an effective basis for teaching writing remains in the domain of theory in the context of the study site. The effective practical implementation of the writing tasks cannot be maintained unless the students have awareness about the writing tasks. Therefore, an intensive awareness-raising training about the effects of the writing tasks, their relevance, the roles to be played and how the writing tasks should be practiced ought to be given to the students.

3. Teachers should work exhaustively to overcome students' misunderstandings at the beginning of the academic year so that they can effectively involve in the writing tasks in the textbook.

4. Teachers should also be determined and committed to apply TBLT principles in the real classroom practices of teaching writing.

5. Students should also actively participate in each phase of the writing activities for the betterment of their writing.

\section{REFERENCES}

Abas A. 2016. An assessment of teaching writing skill in the current context of English language teaching: the case of two high schools in Arsi zone. MA Thesis. Haramaya University, Haramaya, Ethiopia.

Al-Azani, N.A. 2015. Exploring English Instructors' Perceptions and actual Practices regarding the Strategies used in Teaching and Assessing Writing in three Tertiary Education Institutions in the Sultanate of Oman. MA Thesis, United Arab Emirates University, Oman.

Amlaku E. 2013. Language Policies and the Role of English in Ethiopia 1.A conference Paper presented at the 23rd Annual Conference of IATEFL BESIG (19-21 Nov. 2010), Bielefeld, Germany.

Ary, D., Jacobs, L.C., Sorensen, C. and Razavieh, A. 2010. Introduction to Research in Education. Wadsworth Cengage learning, USA.

Asadifard, A. 2013. EFL Instructors and Student Writers ${ }^{e e}$ Perceptions on Academic Writing Reluctance. Theory and Practice in Language Studies, 3(9). 1572-1578.

Beyene G. 2008. Perception and Classroom Practice of Communicative Language Teaching by High School EFL Teachers and Learners: The case of Some Selected High Schools in Addis Ababa. MA Thesis, Addis Ababa University, Addiss Ababa, Ethiopia.

Bygate, M. 2003. Effects of Task Repetition: Appraising the Development of Second Language Learners. In J. Willis and D. Willis (eds). Challenge andChange inLanguage Teaching. Heinemann, Oxford, England.

Cohen, L., Manion, L. and Morrison, K. 2000. Research Methods in Education. Rutledge Palmer Taylor \& Francis Group, London and New York, UK.

Creswell, J. W. 2014. Qualitative, Quantitative and Mixed Method Approaches. SAGE Publications Ltd. California, USA.

Daniel D. 2010. An Exploration into Perceptions of Junior Secondary School English Teachers towards Communicative Language Teaching and Their Actual Classroom Practices: Grade 8 in Focus. MA Thesis, Addis Ababa University, Addis Ababa, Ethiopia.

Dawit A. 2013. Enhancing Students' Writing Skills through the Genre Approach. International Journal of English and Literature, 3 (8): 242-248.

DemelashY. 2011. An exploration of English Language Teachers' and Students' Perception and Implementation of Task-based Activities: the Case of Pwo Preparatory Schools in Wolaita zone. MA Thesis, Haramaya University, Haramaya, Ethiopia.

Eliss, R. 2003. Task Based Language Learning and Teaching. Oxford University Press, Oxford, England.

Flynn, N. and Stainthorp, R. 2006. The Learning and Teaching of Reading and Writing. Whurr Publishers Ltd, England.

Griffe, D. T. 2012. An Introduction to Second Language Research Methods Design and Data. TESL-EJ Publications, USA.

Ismail, S.A. 2011. Exploring Students' Perceptions of ESL Writing. English Language. Teaching, 4(2), 73-83. 
Kamil, I. 2011. Perceptions of Kuwaiti EFL Student - Teachers towards EFL Writing, and Methods of Teaching and Learning EFL Writing. Doctoral Dessertation, University of Exeter, Kuwaiti.

Kumaravadievlu, B. 1993. Maximizing Learning Potential in the Communicative Classroom. ELT Journal, 47(1): 12-18.

Meron M. 2015. Evaluation of Writing Tasks: Grade Nine New Textbook in Focus. MA Thesis, Addiss Ababa University, Addis Ababa, Ethiopia.

Meseret T. 2012. Instructors' and Students Perceptions and Practices of Task Based Writing in An EFL context. Doctoral Dissertation, Addiss Ababa University, Addiss Ababa, Ethiopia.

Nunan, D. 2004. Task Based Language Teaching, Cambridge University Press, Cambridge, UK.

Patton, M. Q. 1990. Qualitative Evaluation and Research Methods. Sage, London, UK.

Prabhu, N. 1987. Second Language Pedagogy. Oxford University Press, Oxford, UK.

Richards, J.C. and Rodgers, T.S. 2001. Approaches and Methods in Language Teaching. Cambridge University Press,New York, USA.

Robson, C. 2002. Real world research: A Resource for Social Scientists and Practioner Researchers. Blackwell printing press, UK.

Stevick, E. (1996). Memory, Meaning and Method, 2nd ed. Boston, MA, USA

Tagesse A. 2012. Exploring Tensions between English Teachers' Beliefs and Practices in Teaching Writing.The International HETL Review, 2 (11): 98 - 114.

Tariku M. 2013. An Evaluation of the Writing Tasks and their Implementation: the Case of Grade 11 English Textbook. MA Thesis, Addiss Ababa University, Addiss Ababa, Ethiopia.

Taye G. 2008. Perceptions and Practices of Active Learning in EFL classes of Dilla University. MA Thesis, Dilla University, Dilla, Ethiopia.

William, D.C. and Marilynn, B. B. 2002. Principles and Methods of Social Research (2 ${ }^{\text {nd }}$ ed $)$.Lawrence Erlbaum Associates, Publishers, New Jersey, USA.

Willis, J. 1996. A Framework for Task Based Learning. Longman,London, England. 